\title{
Exploration of the antibacterial and chemical potential of some Beninese pharmacopoiea traditional plants
}

\author{
Boris Lègba, ${ }^{1}$ Victorien Dougnon, ${ }^{2}$ Angèle Ahoyo, ${ }^{2}$ Jerrold Agbankpè, ${ }^{2}$ Gildas Hounmanou, ${ }^{2}$ \\ Alidah Aniambossou, ${ }^{2}$ Edna Hounsa, ${ }^{2}$ Kafayath Fabiyi, ${ }^{2}$ Affousssath Amadou, ${ }^{2}$ Phénix Assogba, ${ }^{2}$ \\ Honoré Bankolé, ${ }^{2}$ Jacques Dougnon, ${ }^{2}$ Lamine Baba-Moussa ${ }^{1}$
}

${ }^{1}$ Laboratory in Biology and Molecular Typing in Microbiology, Faculty of Sciences and Techniques, ${ }^{2}$ Research Unit in Applied Microbiology and Pharmacology of Natural Substances, Research Laboratory in Applied Biology, Polytechnic School of Abomey-Calavi, University of Abomey-Calavi, Cotonou, Benin

\begin{abstract}
Summary
Objectives. This study aims to evaluate the antibacterial and chemical properties of some medicinal plants used in the fight against enteropathogens in Benin.

Methods. Aqueous and ethanolic extracts of Senna siamea, Uvaria chamae, Lantana camara and Phyllantus amarus were tested on 10 bacterial strains. Well diffusion technique, coupled with the microdilution determination of Minimum Inhibitory Concentration (MIC) and Minimum Bactericidal Concentration
\end{abstract}

Correspondence: Victorien T. Dougnon, Lecturer-Researcher in Microbiology, Polytechnic School of Abomey-Calavi, University of Abomey-Calavi, Cotonou, Benin.

Tel.: +229.97.736446.

E-mail: victorien88@hotmail.com

Key words: Enteropathogens, salmonellosis in Benin, beninese pharmacopoiea.

Acknowledgments: The authors are very grateful to The World Academy of Science for the Advancement of Science in Developing Countries (TWAS) and the United Nation Educational, Scientific and Cultural Organization (UNESCO). These two institutions have made this research possible through research funding allocated to the research team under the number: 487 RG/BIO/AF/AC_G-FR3240293303.

Contributions: the authors contributed equally.

Conflict of interest: the authors declare that they have no conflict of interest.

Received for publication: 16 August 2017.

Revision received: 6 November 2017.

Accepted for publication: 19 January 2018.

(C) Copyright B. Lègba et al., 2017

Licensee PAGEPress, Italy

Microbiologia Medica 2017; 32:6998

doi:10.4081/mm.2017.6998

This article is distributed under the terms of the Creative Commons Attribution Noncommercial License (by-nc 4.0) which permits any noncommercial use, distribution, and reproduction in any medium, provided the original author(s) and source are credited.
(CMB) was used for antibacterial testing. The larval cytotoxicity was evaluated by using Artemia salina crustacean larvae. flavonoids and polyphenols were also assayed by the method using aluminum trichloride $(\mathrm{AlCl} 3)$ and the method using the folin-Ciocalteu reagent, respectively.

Results. The results of the study revealed that extracts had an effective antibacterial activity at $100 \mathrm{mg} / \mathrm{mL}$, with MIC between 100 and $25 \mathrm{mg} / \mathrm{mL}$ and $\mathrm{CMB}$ between 100 and $50 \mathrm{mg} / \mathrm{mL}$. The inhibition diameters of the extracts varied between 7.5 and 21 $\mathrm{mm}$. The ethanolic extract of Phyllantus amarus leaves showed the best antibacterial activity. None of the extracts tested was found to be cytotoxic at the dose of $20 \mathrm{mg} / \mathrm{mL}$. The aqueous Uvaria chamae root extract has the highest polyphenol content (231.896552 \pm 0.27586207 in $\mu \mathrm{g}$ EAG/100 mg extract), whereas the aqueous leaf extract of Uvaria chamae is the richest in flavonoids (41.061082 0.43180737 in $\mu \mathrm{g} E R / 100 \mathrm{mg}$ of extract).

Conclusions. These interesting results can be used in the development of improved traditional medicines against enteropathogens.

\section{Introduction}

Infections caused by enteropathogens are serious forms of infectious pathology. They are a major public health problem that causes millions of deaths a year. This is the case, for example, of foodborne illnesses, causing 17 million deaths a year worldwide, more than half of which come from the African continent (37). Diarrheal diseases are also the cause of 550 million patients each year, including 220 million children under 5 years of age (37). Salmonella, shigella and klebsielles are amongst others epidemiologically active enterobacteria involved in serious infectious diseases.

Health management of enteropathogenic diseases is achieved through the use of antibiotics, but their inadequate and often anarchic use has resulted in bacterial resistance $(24,36)$. Indeed, recent data from the bibliography abound with descriptions of bacteria that are multiresistant or even toto-resistant to antibiotics. The number of these bacteria is increasing in both industrialized and developing countries (32). This development of microbial resistance to antibiotics has led researchers to carry out alternative investigations to identify other effective natural remedies against various pathologies in the plant kingdom (18). It has therefore proved essential to look for new antibacterial substances that are effective and have a broad spectrum of action. One of the effective strategies for this research is to explore plants used in traditional 
medicine (8). This position is further reinforced by the fact that herbal medicines are of considerable importance in international trade. More than 120 compounds from plants are now used in modern medicine and almost $75 \%$ of them are used according to their traditional use (11). The World Health Organization estimates that $80 \%$ of the African population still uses traditional medicine to treat themselves (31).

In Benin, several plants are used in the traditional treatment of various pathologies, including infectious diseases $(3,4)$. Infectious pathologies related to enteropathogens are well documented. An ethno-pharmacological survey identified 56 medicinal plants used in the treatment of salmonellosis in Benin, including Senna siamea (Lam.) H.S. Irwin \& Barneby, Phyllantus amarus, Uvaria chamea, and Lantana camara (15). These plants have been the subject of few pharmacological studies and are still unexploited from both the antibacterial and chemical point of view, aiming at their traditional valorization. This is why this study was initiated. It aimed to evaluate the antibacterial, pytochemistry ans cytotoxic properties of these plants used against the bacteria responsible for infections.

\section{Materials and Methods}

\section{Equipment}

Laboratory consumables, microbiology and chemistry materials were used during the work. The biological material consists, on the one hand, of the larvae eggs of Artemia salina acquired at the Laboratory of the Benin Center for Scientific and Technological Research (CBRST). On the other hand, the clinical strains Klebsiella pneumoniae, Klebsiella rhinocleromatis, Klebsiella oxytoca, Shigella flexneri, Pseudomonas oryzihabitans, Citrobacter freundi, Salmonella cholerasius, Escherichia coli, Pseudomonas aeruginosa and the reference strain Escherichia coli ATCC25992 were acquired at the National Public Health Laboratory, Ministry of Public Health of Benin. Four (4) medicinal plants formed the vegetal material: leaves of Senna siamea (Lam.) H.S.Irwin \& Barneby (Leguminosae $\square$ Caesalpinioideae), Lantana camara (verbenaceae), Uvaria chamae (Annonaceae), leaves and roots of Phyllanthus amarus Schumach \& Thonn.

\section{Methods}

\section{Collecting plant samples and obtaining powders}

Selected plant organs were collected at Porto-Novo, Calavi and Adjarra in April 2017. The plants are identified at National Herbarium of Benin Of University of Abomey-Calavi. Reference numbers are AA6686/HNB for Phyllantus amarus, AA6687/HNB for Uvaria chamae, AA6688/HNB for Lantana Camara, AA6691/HNB for Senna siamea. The organs were dried in the laboratory at a temperature of $16^{\circ} \mathrm{C}$ for 10 days. The dried material was then powdered using a Retsch SM 2000/1430/Upm/Smf type mill. The powders obtained were identified and stored in plastic jars at room temperature in the laboratory.

\section{Production of aqueous and ethanolic extracts}

The aqueous and ethanolic total extracts were obtained by adaptation of the method developed by Guede-Guina et al. (17). Fifty grams of powder were macerated in $500 \mathrm{~mL}$ of distilled water or ethanol on a Stuart Bioblock Scientific Fisher stirrer for 72 hours at room temperature. The resulting homogenate was filtered three times on hydrophilic cotton followed by filtration on Wattman No. 1 paper. This filtrate was then dried at $45^{\circ} \mathrm{C}$ in the
Pasteur oven. The powder thus obtained was the total aqueous or ethanolic extract.

\section{Larval cytotoxicity}

The cytotoxic effect of the extracts was evaluated according to an adaptation of the method described by Kawsar et al. (22). The tests were carried out on larvae obtained by hatching $10 \mathrm{mg}$ of Artemia salina eggs (ARTEMIO JBL GmbH D-67141 Neuhofem) under continuous stirring in one liter of seawater for 72 hours. To one $\mathrm{mL}$ of each dilution in geometric series 2 of extract prepared from a stock solution of $40 \mathrm{mg} / \mathrm{mL}$ is added $1 \mathrm{~mL}$ of seawater containing 16 larvae. The number of surviving larvae was counted after $24 \mathrm{~h}$ of incubation. The LC50 was determined from the regression line obtained from the curve representative of the number of surviving larvae as a function of the concentration of the extracts. To interpret these results, correlation grids associating the degree of toxicity with $\mathrm{LC} 50$ have been proposed: $\mathrm{CL}_{50} \geq 0.1$ $\mathrm{mg} / \mathrm{mL}$ (the extract is non-toxic), $0.1 \mathrm{mg} / \mathrm{mL}>\mathrm{CL}_{50} \geq 0.050$ $\mathrm{mg} / \mathrm{mL}$ (low toxicity), $0.050 \mathrm{mg} / \mathrm{mL}>\mathrm{CL}_{50} \geq 0.01 \mathrm{mg} / \mathrm{mL}$ (medium toxicity), $\mathrm{CL}_{50}<0.01 \mathrm{mg} / \mathrm{mL}$ (high toxicity) (27).

\section{Implementation of antibacterial tests}

Preparation of extracts and sterility testing of extracts. The aqueous and ethanolic extracts of each plant were taken up in distilled water at a rate of $100 \mathrm{mg}$ per $1 \mathrm{~mL}$. Stock solutions containing $100 \mathrm{mg} / \mathrm{mL}$ were thus prepared. They were then sterilized in an autoclave at $121^{\circ} \mathrm{C}$. for 15 minutes. The sterility of the stock solutions of extracts was verified by inoculating aliquots of each solution on the Mueller Hinton medium according to the methodology described by Agbankpe et al. (5).

Preparation of bacterial suspension. A 24-hour pure colony portion from the Mueller Hinton medium of each strain was emulsified in $5 \mathrm{~mL}$ of physiological water to give a turbidity of 0.5 on the Mc Farland scale (CA-SFM, 2017).

Realization of the antibiogram by the diffusion technique in wells. Each inoculum was seeded by swab on Petri dishes containing Mueller Hinton agar (CA-SFM, 2017). With the aid of the sterile Pasteur pipette tip, wells of $6 \mathrm{~mm}$ diameter were hollowed out. Then, using a cone and a micropipette, $50 \mu \mathrm{L}$ of each extract was deposited in the wells previously excavated. A well containing sterile distilled water served as a negative control. The Petri dishes were left for 1 hour at room temperature for pre-diffusion of the substances and incubated at $37^{\circ} \mathrm{C}$ in an oven for 18 hours (30). Standard antibiotic discs were also used to serve as positive controls. The test was repeated three times. After the incubation period, the dishes were examined for the measurements of the zones of inhibition. The antibacterial activity of the extracts was determined from the diameters of zones of inhibition around the wells. The standard used for reading the results of the antibiogram tests is presented in Table 1.

Determination of minimum inhibitory concentration and minimum bactericidal concentration. This step was performed using the 96-well plate method described by Houngbeme et al. (19). 100 $\mu \mathrm{L}$ of the stock solution of each extract prepared at $200 \mathrm{mg} / \mathrm{mL}$ were added to $100 \mu \mathrm{L}$ of Mueller-Hinton Broth. A series of twofold dilution from well to well was made then $100 \mu \mathrm{L}$ of different bacterial suspensions were added. Positive and negative controls were prepared respectively by adding $100 \mu \mathrm{L}$ of $\mathrm{MH}$ broth to 100 $\mu \mathrm{L}$ of bacterial suspension and $100 \mu \mathrm{L}$ of $\mathrm{MH}$ broth to $100 \mu \mathrm{L}$ of the extracts. The microplates were coated with parafilm paper and incubated at $37^{\circ} \mathrm{C}$ for 24 hours. The MIC was estimated with the naked eye compared to the controls and each well was cultured on Agar MH Agar and incubated at $37^{\circ} \mathrm{C}$ for 24 hours for the determi- 
nation of $\mathrm{CMB}$. $\mathrm{CMB}$ is the lowest concentration of extract to which no colony of bacteria can be observed. The antibiotic potency (a.p) of each extract was then calculated with the formula $\mathrm{CMB} / \mathrm{CMI}$.

\section{Determination of bioactive compounds}

Determination of polyphenols. The total phenols were assayed by a method adapted from that of Singleton (35) using the commercial folin-Ciocalteu reagent. The total polyphenol content in the various extracts was calculated from a linear calibration curve $(y=a x+b)$, established with precise gallic acid concentrations as a reference standard (0-200 $\mathrm{mg} / \mathrm{L})$. Each sample tested was dissolved in methanol so as to obtain a concentration of $10 \mathrm{mg} / \mathrm{mL}$ and then diluted to $1 / 100$ with distilled water. A volume of $125 \mu \mathrm{L}$ of diluted solution was then mixed with $625 \mu \mathrm{L}$ of the $10 \%$ FolinCiocalteu reagent (10 times diluted in distilled water) and incubated for $5 \mathrm{~min}$. $500 \mu \mathrm{L}$ of an aqueous solution of sodium carbonate $\left(\mathrm{Na}_{2} \mathrm{CO}_{3}\right)$ at $75 \mathrm{~g} / \mathrm{L}$ are then added and mixed with the vortex and incubated for $2 \mathrm{~h}$. After incubation, the optical densities (OD) were read at $760 \mathrm{~nm}$ using a CECIL CE 2041 spectrophotometer. Three readings were made per sample. The reading was made against a blank consisting of a mixture of $0.5 \mathrm{~mL}$ of FCR and $1 \mathrm{~mL}$ of $\mathrm{Na} 2$ $\mathrm{CO} 3$. The total phenol contents are determined using a gallic acid calibration curve $(0-200 \mathrm{mg} / \mathrm{L})$.

Determination of flavonoids. The contents of the flavonoids were measured by a suitable method of Zhishen et al. (38) and Kim et al. (23) using aluminum trichloride $(\mathrm{AlCl} 3)$ as reagent. The presence of a free cell in the reagent $\mathrm{AlCl} 3$ forms a dative bond with the oxygen-free doublets of the $\mathrm{OH}$ groups of the flavonoids, producing a yellow complex whose maximum absorbance is recorded at $415 \mathrm{~nm}$. The quantities of flavonoids in our extracts were calculated from the calibration curve of a standard flavonoid (rutin) as a reference standard $(0-200 \mathrm{mg} / \mathrm{L})$. To $500 \mu \mathrm{L}$ of a solution of $\mathrm{AlCl} 3$ ( $2 \%), 500 \mu \mathrm{L}$ of the sample is added. $3 \mathrm{~mL}$ of methanol are added to this mixture. The blank consists of $500 \mu \mathrm{L}$ of $\mathrm{AlCl} 3$ and $3.5 \mathrm{~mL}$ of methanol. Absorbance reading is done at the spectrophotometer at $415 \mathrm{~nm}$ after $10 \mathrm{~min}$ incubation.

\section{Statistical analysis}

The sensitivity tests were repeated three times and the results analyzed using the Graph Pad 7 software. They were then presented on average \pm SD. An analysis of variance (ANOVA single factor) was used to compare the means of the zones of inhibition between the two extracts of the same plant. The level of significance was set at $5 \%$.

For larval cytotoxicity, the LD50 of the extracts tested will be determined with the Microsoft Excel 2010 software, starting from the regression line obtained from the curve representing the number of surviving larvae as a function of the concentration of the extracts. For easy manipulation of the results, the following coding was adopted: Ss=Senna siamea (Lam.) H.S. Irwin \& Barneby; $\mathrm{Ucl}=$ Uvaria chamae leaf; Ucr=Uvaria chamae roots,
$\mathrm{Pa}=$ Phyllantus amarus; Lc=Lantana camara; EA=Aqueous Extract; EE=Ethanolic Extract.

\section{Results}

\section{Extraction yield and sterility test}

The yields at extraction vary from one plant to another and from one extract to another. The highest yield is obtained with the ethanolic extract of L. camara (19.12\%) while the lowest yield $(5 \%)$ is obtained with the aqueous extract of $P$. amarus (Figure 1). Sterility tests revealed no contamination at all of the extracts.

\section{Larval cytotoxicity of extracts}

The Artemia salina model was chosen in particular for its relatively quick and inexpensive implementation. The results of the larval cytotoxicity test revealed a sensitivity of larvae of Artemia salina to the extracts of all plants at a dose of $20 \mathrm{mg} / \mathrm{mL}$. Figure 2 shows the regression curve which expresses the percentage of larvae killed as a function of concentration for the aqueous extract of Senna siamea (Lam.) H.S. Irwin \& Barneby.

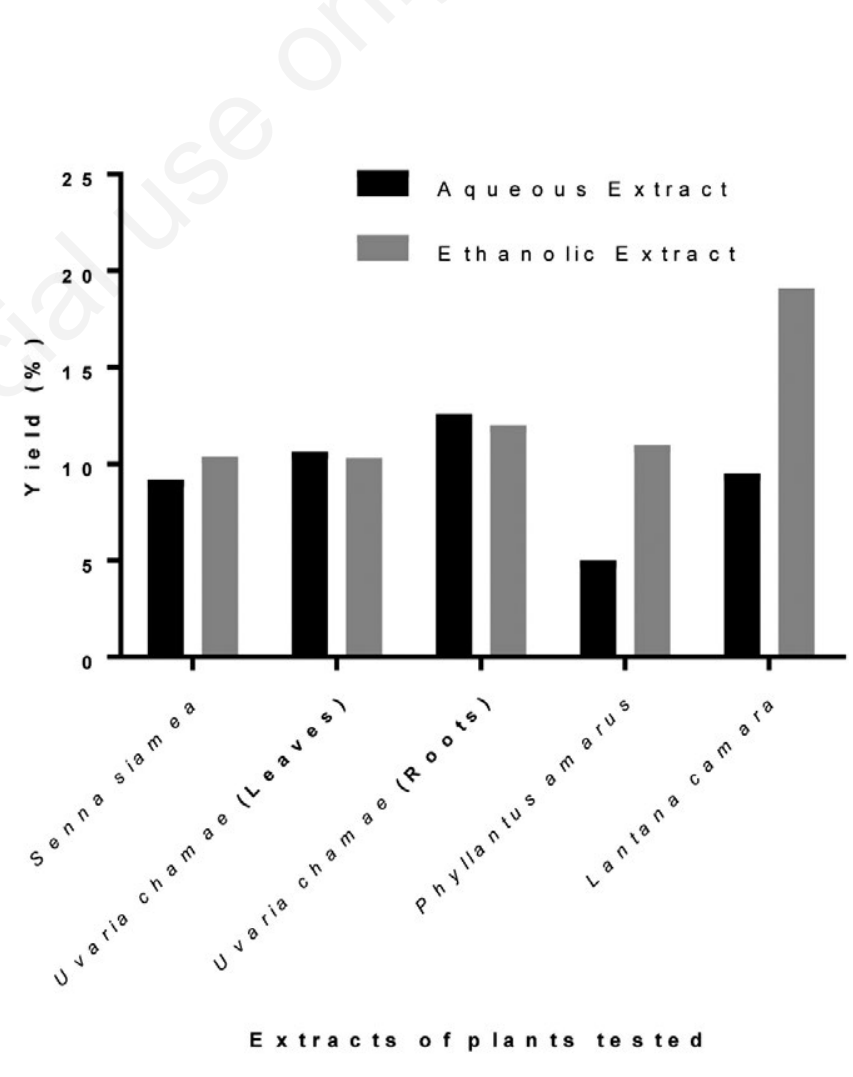

Figure 1. Extraction yield.

Table 1. Standard values used to interpret the results of the susceptibility tests the plant extracts.

\begin{tabular}{lc} 
Diameter of the inhibition zone (D) & Degree of sensitivity of the germ \\
$\Delta<7 \mathrm{~mm}$ & Resistant \\
$7 \mathrm{~mm} \leq \Delta<8 \mathrm{~mm}$ & Sensitive \\
\hline $8 \mathrm{~mm} \leq \Delta<9 \mathrm{~mm}$ & Moderately sensitive \\
$\Delta \geq 9 \mathrm{~mm}$ & Very sensitive \\
\hline
\end{tabular}


The LC50 lethal dose is determined from the regression curve which expresses the percentage of larvae killed as a function of the concentration of the extracts. The lethal doses and regression coefficients of the extracts of all the plants studied are reported in Table 2.

All extracts have an LC50 greater than $0.1 \mathrm{mg} / \mathrm{mL}$. All extracts are therefore non-cytotoxic with respect to larvae of Artemia salina.

\section{Antibacterial tests}

\section{CMI, CMB and AP of the plant extracts studied on the strains tested}

The Minimum Inhibitory Concentration (MIC), Minimum Bactericidal Concentration (CMB) and the antibiotic potency (AP) of the plant extracts studied on the tested strains are summarized in Table 3. The aqueous extract of Senna siamea (Lam.) HS Irwin \& Barneby., The ethanolic root extract of Uvaria chamae, and the ethanolic extract of Lantana camara has no antibiotic power on the strains tested. With the exception of the ethanolic root extract of Uvaria chamae, which for the K.oxytoca strain has a MIC of 50 $\mathrm{mg} / \mathrm{m}$, these three extracts possess, on all the sensitive strains, a MIC of $100 \mathrm{mg} / \mathrm{mL}$. The ethanolic extract of Uvaria chamae leaf and the ethanolic extract of the leaves of $P$. amarus have a bactericidal effect on $30 \%$ of the strains tested. The aqueous extract of $P$. amarus leaves has a bacteriostatic effect on K.pneumoniae and P.oryzihabitans, a bactericidal effect on Sh.flexneri (Table 3).

\section{Sensitivity tests}

The results of the susceptibility tests of the strains used to the extracts of the plants studied are summarized in Figure 3. The tested strains exhibit a variable sensitivity with regard to the extracts tested. The inhibition diameters of the extracts vary between 7.5 and $21 \mathrm{~mm}$. The ethanolic extract of leaves of Phyllantus amarus possesses the best antibacterial activity. The extract is very active $(+++)$ on $50 \%$ of the strains and has the largest diameter of inhibition of the extracts on the strains (21 mm on Sh.flexneri). All extracts, except aqueous extract of $P$. amarus, are active on $K$. oxytoca. Only the ethanolic extract of L.camara is very active (+++) on C.freundi, with an inhibition diameter of $20.5 \pm 0.71$.

Only the aqueous leaf extract of U.chamae is active on E. coli (reference strain) with an inhibition diameter of $14 \mathrm{~mm}$. With the exception of E.coli, which is sensitive $(+)$ to the ethanolic leaf extract of U.chamae, S.cholerasius and P.aeruginosa which are sufficiently sensitive $(++)$ to the aqueous leaf extract of U.chamae, all strains which exhibit sensitivity to extracts showed an inhibition diameter greater than $9 \mathrm{~mm}$, and therefore a very high sensitivity $(+++)$.
Furthermore, there was a significant difference between the inhibition diameters of ethanolic extract and aqueous extract of all studied plants, on all tested strains $(\mathrm{P}<0.05)$.

\section{Total polyphenols and flavonoids content of extracts}

The total phenolic compound contents of the extracts (Figure 4) were determined with reference to a standard curve $(y=0.058 \mathrm{x}-$ 0.015 ) of gallic acid with $y$ readout absorbance and $\mathrm{x}$ concentration (Figure 5). The total flavonoid contents of the extracts were determined with reference to a standard curve $(y=0.191 x-0.008)$ of the rutin (Figure 6).

The aqueous root extract of Uvaria chamae has the highest total polyphenol content $(231.896552 \pm 0.27586207$ in $\mu \mathrm{g}$ EAG/100 mg of extract), whereas the aqueous extract of $P$. amarus leaves has the most Low $(35.6321839 \pm 0.268575$ in $\mu \mathrm{g}$ EAG/100mg). All extracts have a flavonoid content less than the content of polyphenols. The aqueous leaf extract of U.chamae had the highest flavonoid content $(41.061082 \pm 0.43180737$ in $\mu \mathrm{g}$ ER/100 mg extract) whereas the aqueous extract of Senna siamea leaf had the lowest Content of total polyphenols (1.59162304 \pm 0.33507853 in $\mu \mathrm{g} \mathrm{ER/100} \mathrm{mg} \mathrm{of} \mathrm{extract).}$

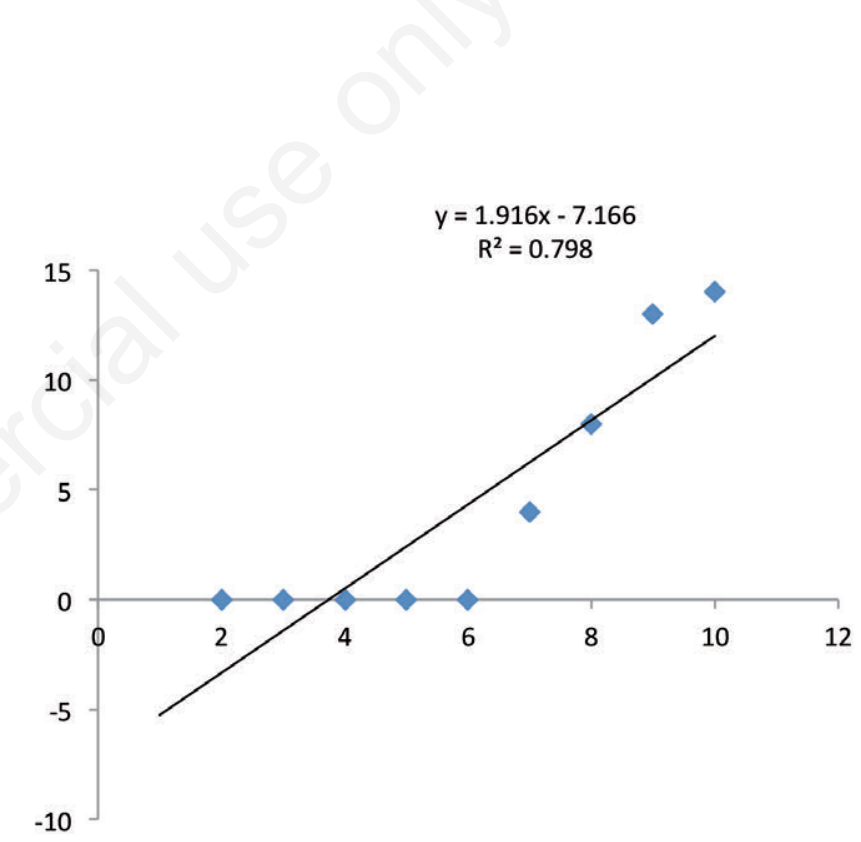

Figure 2. Sensitivity of larvae of Artemia salina to aqueous extract of Senna siamea (Lam.) H.S. Irwin \& Barneby.

Table 2. LC50 (mg/mL) and Regression coefficient $\left(\mathbf{r}^{2}\right)$ for all extracts of plants studied.

\begin{tabular}{lcc} 
Extracts & $\mathrm{CL}_{50}(\mathrm{mg} / \mathrm{mL})$ & Regression coefficient $\left(\mathrm{r}^{2}\right)$ \\
Cs AE & 10.31 & 0.910 \\
Cs EE & 10.59 & 0.896 \\
\hline Ucf AE & 3.04 & 0.938 \\
Ucf EE & 6.47 & 0.914 \\
\hline Ucr AE & 8.689 & 0.818 \\
Ucr EE & 7.5231 & 0.946 \\
\hline Pa AE & 5.9271 & 0.985 \\
Pa EE & 5.3254 & 0.990 \\
Lc AE & 5.12 & 0.959 \\
LcEE & 5.2498 & 0.986
\end{tabular}




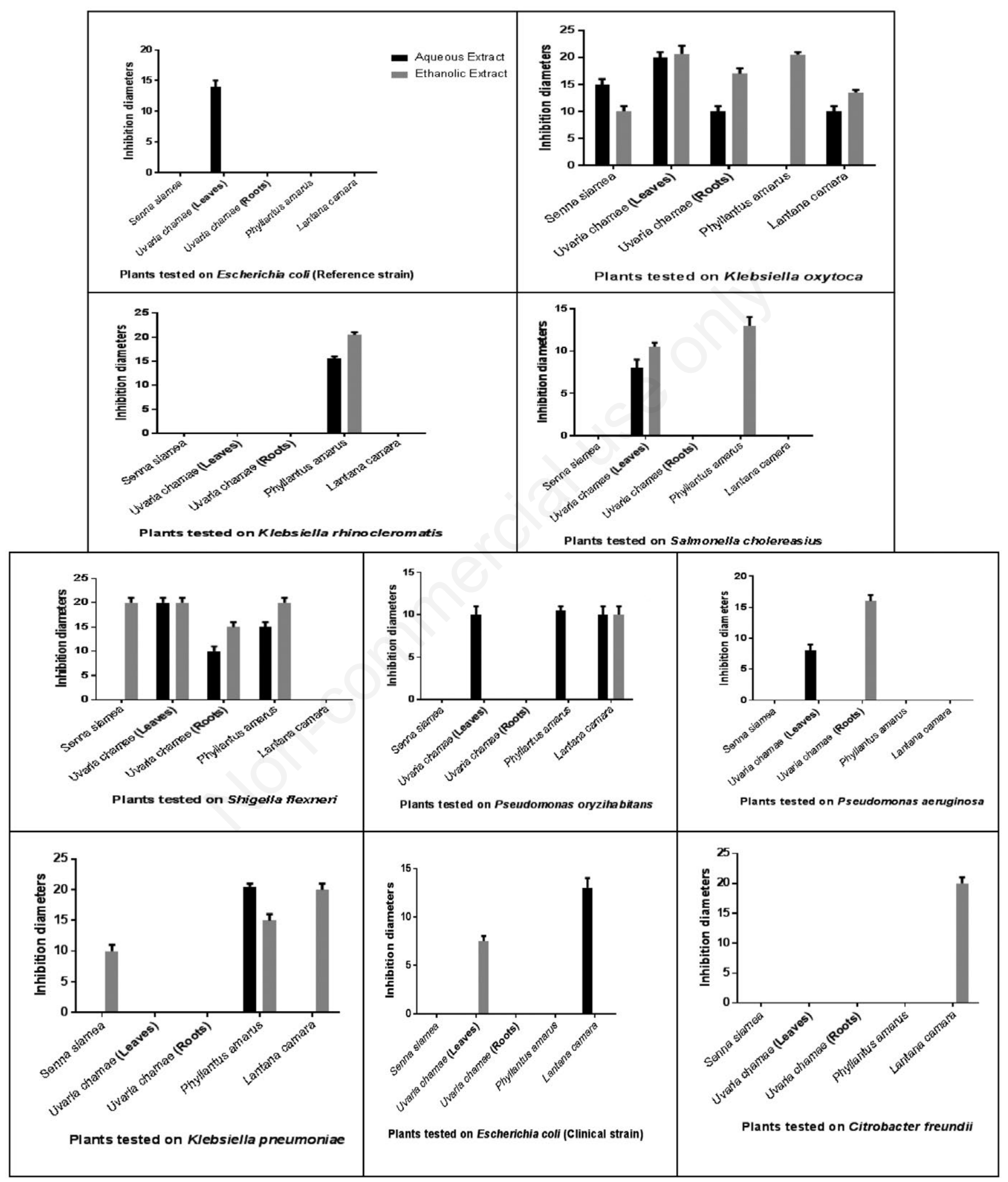

Figure 3. Diameter of inhibition of the extracts of the plants studied on the bacterial strains. 


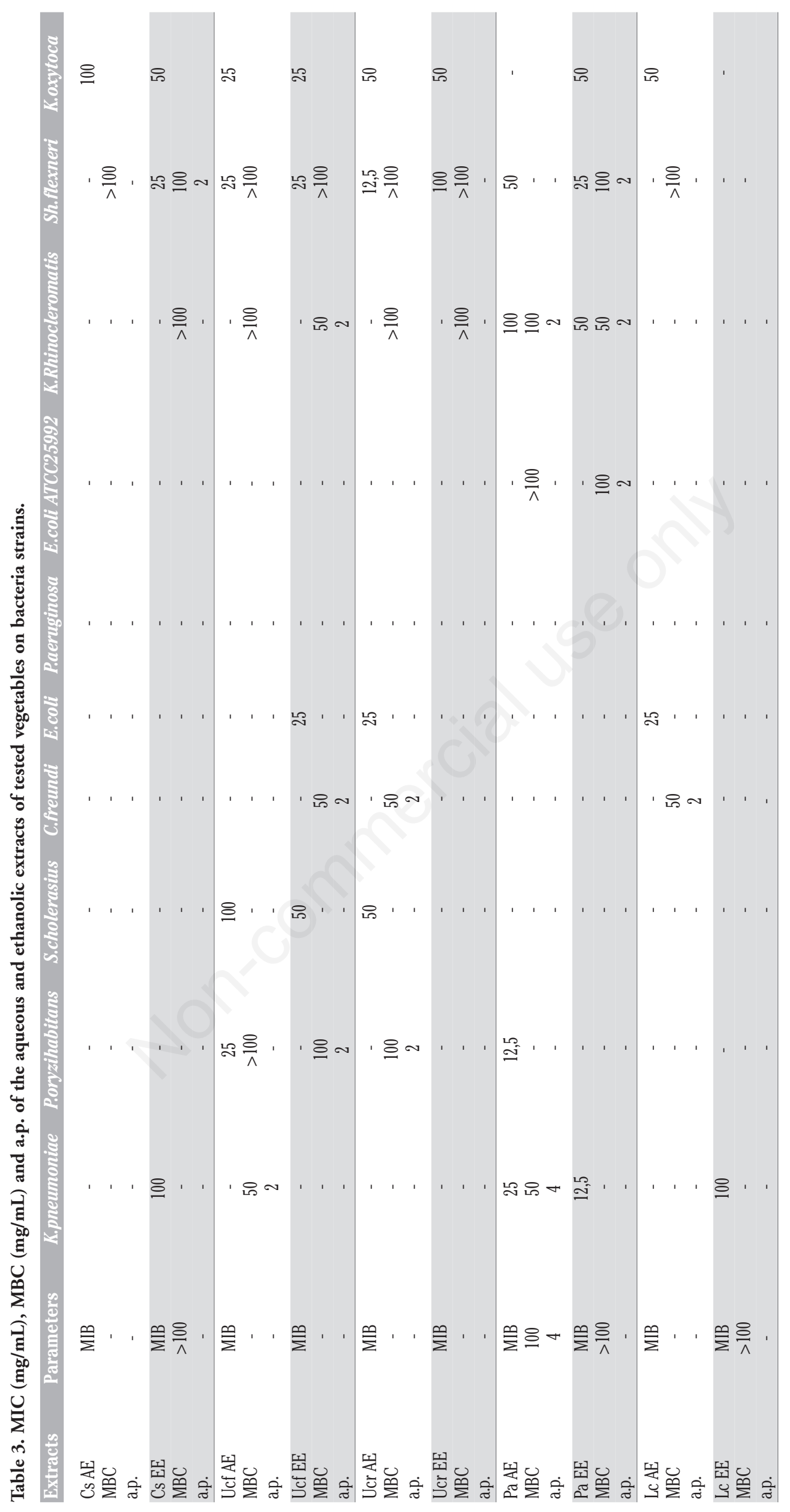




\section{Discussion}

The yield expressed as the percentage of active ingredients extracted by the solvent. It is an important parameter for discussing the biological activities of an extract. The variability of the yields obtained at the end of the extraction could be explained by the extraction capacity of each solvent. Indeed, the affinity of this solvent with respect to the phytomolecules and its polarity influences the yield (12). With the exception of the extracts of U.chamae, the yield of the ethanol extract of all the plants studied is higher than that of the aqueous extract. The high yields obtained with ethanol suggest that most of the active ingredients are soluble in ethanol and are therefore extractable by this solvent, which is normal since the alcohol is much more polar than water. It is the reverse for the extracts of U.chamae for which water manages to extract the largest number of active ingredients. This difference from the other extracts would be due to the extraction conditions. The aqueous extract of Senna siamea (Lam.) H.S. Irwin \& Barneby. Yielded nearly $50 \%$ less than the $18.32 \%$ obtained by Ahonsou (7). This discrepancy may be due to several reasons. These include the level of maturity of the collected leaves, the extraction process, the geographical origin of the plant drug, leaf drying conditions (2), harvest time, degree of purity and quality of the solvents used.

All extracts have an LC50 greater than $0.1 \mathrm{mg} / \mathrm{mL}$. The extracts of the plants studied at a dose of $20 \mathrm{mg} / \mathrm{mL}$ are therefore non-toxic to shrimp larvae cells according to the scale proposed by Sparkling (27). The cytotoxicity test according to the Artemia salina model constitutes a preliminary screening to determine not only the degree of cytotoxicity of a product, but also the presence of potential anti-cancer compounds. There is a positive correlation between the mortality of Artemia larvae and cytotoxicity against $\mathrm{KB}$ cells (26). This test therefore constitutes a preliminary antitumor screening of plant extracts. It can be said that the extracts of the plants studied are non-cytotoxic to human cancer cells at a dose of $20 \mathrm{mg} / \mathrm{mL}$. This is true that some authors claim that there is no correlation between this test and The toxicological effects on a whole animal (33) but for 20 plant extracts tested using in vivo (mouse) and in vitro methods (25). A good correlation ( $\mathrm{r}=0.85$, $\mathrm{P}<0.05$ ), suggesting that the Artemia test is a relatively useful alternative toxicity model.

The results of our study agree with those of Agbodjogbe et al. (6) who found an LC50 of $0.78 \mathrm{mg} / \mathrm{mL}$ for the aqueous extract of Senna siamea (Lam.) HS Irwin \& Barneby. Cytotoxic effect of the extracts of this medicinal plant. All the extracts of the plants studied showed an interesting antibacterial activity on the strains studied, to varying degrees. This justifies the use of these plants in the treatment of infectious diseases $(3,4,15)$. The aqueous extract of Senna siamea (Lam.) H.S. Irwin \& Barneby was found to be very active on $K$. oxytoca and inactive on the other strains tested whereas the ethanolic extract of Senna siamea (Lam.) H.S. Irwin \& Barneby was very active on $K$. pneumonia and $K$. oxytoca. These results are similar to those of De Souza et al. (13), which demonstrated the resistance of $E$. coli and P. aeruginosa to aqueous extracts of Senna siamea (Lam.) H.S. Irwin \& Barneby. The resistance of the $S$. cholerasius strain calls into question the traditional use of this plant in the treatment of salmonellosis as reported by Dougnon et al. (15). However, this conclusion can not be made without first testing the extracts of this plant on other salmonella strains. The ethanolic extract of leaves of Uvaria chamae was found to be active on $S$. cholerasius, $E$. coli, K. rhinocleromatis with Minimal Inhibitory Concentrations (MIC) of $50 \mathrm{mg} / \mathrm{mL} ; 25$ $\mathrm{mg} / \mathrm{mL}$ and $25 \mathrm{mg} / \mathrm{mL}$ respectively, lined with a bactericidal effect. As for the ethanolic root extract, it was active only on Sh. Flexneri and K.oxytoca with respective MICs of $100 \mathrm{mg} / \mathrm{mL}$ and $50 \mathrm{mg} / \mathrm{mL}$. In Nigeria, Ogbulie made similar observations with respect to ethanolic extracts of $U$. chamae leaves on E. coli and S. typhi strains (28). Contrary results are obtained by Chika et al. (10) who observed the activity of the root-ethanolic extracts of $U$. chamae with a MIC of $72.44 \mathrm{mg} \mathrm{mL-1}$ on E. coli. In this same study, the same extracts show a strong activity on $P$. aeruginosa and $S$. typhi whereas these strains are insensitive to our extracts. Moreover, for the same type of extract (ethanolic), the extracts of two different organs (roots and leaves) of $U$. chamae do not exhibit the same activity on the strains tested. This assumes that the active ingredients extracted at the level of the leaves are not the same at the level of the bark. The aqueous extract of L. camara is very active on $E$. coli with a bactericidal effect and a MIC of $25 \mathrm{mg} / \mathrm{mL}$. This strong

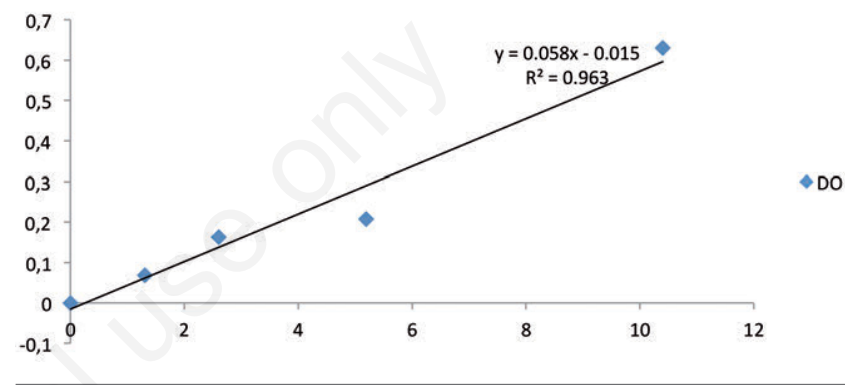

Figure 4. Total polyphenols and flavonoids content of extracts.

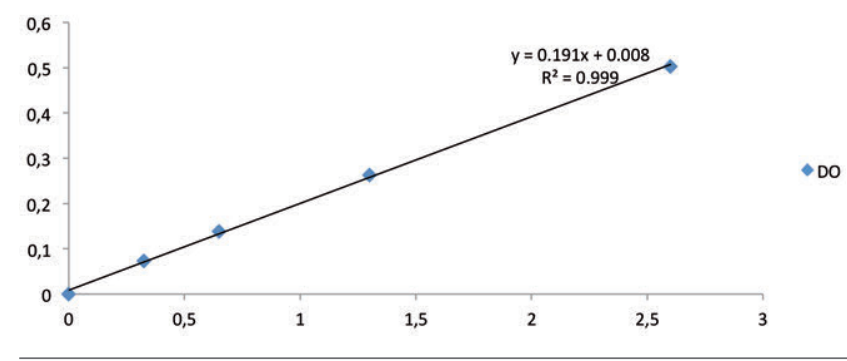

Figure 5. Gallic acid calibration.

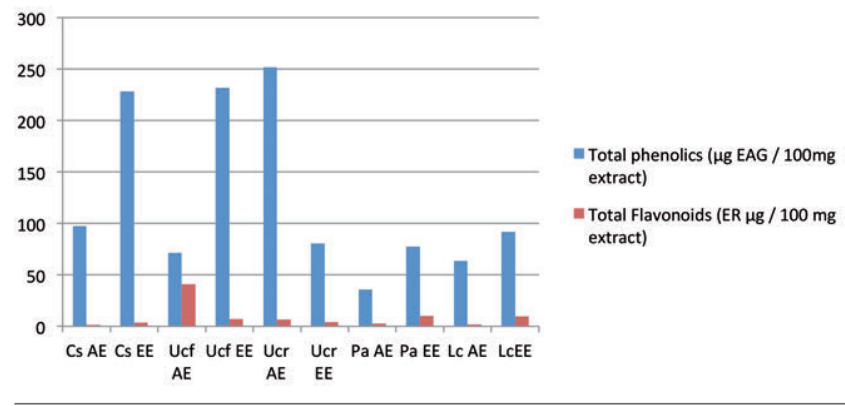

Figure 6. Calibration of rutin. 
activity is already demonstrated in more recent studies such as that of Etchike et al. (16), which demonstrated the bactericidal effect on $E$. coli with a MIC of $(1.47 \times 10)-2$. The same observation was already made rather by Xaserra et Sharma (1999), but this time with the essential oils of the plant. The aqueous and ethanolic extracts of the leaves of Phyllantus amarus were inactive on $P$. aeruginosa and $E$. coli. These findings are in contrast to those of Adebo et al. (1), who found a minimum bactericidal concentration (CMB) of $9.4 \mathrm{mg} / \mathrm{mL}$, a minimum inhibitory concentration (MIC) of $9.4 \mathrm{mg} / \mathrm{mL}$ and A concentration for $50 \%$ inhibition (IC50) of 1.5 $\mathrm{mg} / \mathrm{mL}$ with $P$. aeruginosa. A CMB of $18.7 \mathrm{mg} / \mathrm{mL}$, a MIC of 9.4 $\mathrm{mg} / \mathrm{mL}$ and an $\mathrm{IC} 50=0.9 \mathrm{mg} / \mathrm{mL}$ were revealed with $E$. coli. Differences in susceptibility of strains to extracts in comparison with other studies could have as explanations: the origin of the strains, the isolation techniques, the characteristics of the strains and the manipulation techniques.

All the extracts have a relatively high content of polyphenols and flavonoids, varying from one extract to another. This variability in the chemical composition of polyphenols in the extracts could be explained by the diversity of the plant species and the different solvents used during the extraction. With the exception of the particular case of root extracts of Uvaria chamae, it has been observed that the ethanolic extracts have a higher polyphenol content than the aqueous extracts. This reinforces the observation made during the raw extraction and suggests that the strong polarity of the ethanol makes it possible to extract a greater quantity of polyphenols than the water extracts from it. The interesting antibacterial properties of the plants involved in this study could be explained by their content of polyphenols and flavonoids. Indeed, the ability of an herbal remedy to exert microbial growth inhibitory effects is due to its different components (21). Most of these are plant metabolism products that can be chemically linked to a wide range of substances: phenolic compounds, tannins, anthocyanins, coumarins, alkaloids and flavonoids $(9,20)$. Bioactive compounds such as tannins, sterols and triterpenes, oses and holosides, coumarins and flavonoids have already been demonstrated $(8,25$, 28). Similarly, flavonoids, alkaloids, tannins, phenols have been demonstrated in Uvaria chamae extracts.

\section{Conclusions}

The traditional use of Senna siamea (Lam.) H. S. Irwin \& Barneby., Uvaria chamae, Lantana camara and Phyllantus amarus in the treatment of enteropathogens is justified because of the interesting low-dose antibacterial properties revealed by our study. These biological activities can be explained by the richness of these plants in polyphenols, these secondary metabolites being known for their therapeutic properties including antibiotic potency. These interesting properties, reinforced by the non-cytotoxicity of the extracts, make these plants good candidates for the development of improved traditional medicines for the treatment of enteropathogens. However, additional in vitro and in vivo studies are needed to expand the database on antibacterial properties and toxicity of these plants.

\section{References}

1. Adebo IB, Doumbia I, Aka N, et al. Evaluation de l'activité antibactérienne de Phyllanthus amarus (Euphorbiaceae) sur la croissance in vitro de Mycobacterium tuberculosis. Rev Méd Pharm 2008;21:35-47.
2. Adeyemi KD, Sabow AB, Abubakar A, et al. Les effets du mélange d'huile alimentaire sur la composition des acides gras, Stabilité oxydante et propriétés physico-chimiques de Longissimus thoracis et lumborum muscle chez les chèvres. Anim Sci J 2016;87:1421-32.

3. Adjanohoun E, Adjaktdjè V, Ahyi MRA, et al. Contribution Aux Etudes Ethnobotaniques et Floristiques au Bénin. Paris: ACCT; 1989. p895.

4. Adomou AC, Yedomonhan H, Djossa B, Legba SI. Etude Ethnobotanique des plantes médicinales vendues dans le marché D'abomey-Calavi au Bénin. Int J Biol Chem Sci 2012;6:745-72.

5. Agbankpe A, Dougnon TV, Bankole SH, et al. In vitro antibacterial effects of Crateva adansonii, Vernonia amygdalina and Sesamum radiatum used for the treatment of infectious diarrhoeas in Benin. J Infect Dis Ther 2016;4:281.

6. Agbodjogbe KWDD, Houngbeme AG, Haïdara M, et al. In vitro and in vivo toxicological evaluation of aqueous extracts from beninese plants: Senna siamea leaves and Sarcopcephaluslatifolusstem roots. Int J Pharmacognosy 2017;4:60-70.

7. Ahonsou A. Etude de la phytochimie et des activités biologiques des feuilles de Cassia siamea Linn\&Bar (Caesalpiniaceae) utilisées dans le traitement traditionnel du paludisme au TOGO. Thèse pour l'obtention du diplôme de docteur d'état en Pharmacie. Faculté de Médecine de Pharmacieet d'OdontoStomatologie. Universite De Bamako 2011

8. Biyiti LF, Meko'o DJL, Tamzc V, Amvam Zollo PH. Recherche de l'Activité Antibactérienne de Quatre Plantes Médicinales Camerounaises, Pharm. Méd Trad Afr 2004;13:11-20.

9. Bruneton J. Pharmacognosie, phytochimie - plantes médicinales. 3ème Ed. Techniques et documentations. Paris. 1999.

10. Chika CO, Jude NO, Ifeanyi CO, Anyanwu NB. Antibacterial activities and toxicological potentials of crude ethanolic extracts of Euphorbia hirta. J Am Sci 2007;3:11-6.

11. Cordell GA, Colvard MD. Somethoughts on the futures of ethnopharmacology. J Ethnopharmacol 2005;100:5-14.

12. Dah-Nouvlessounon D, Adoukonou-Sagbadja H, Diarrassouba $\mathrm{N}$, et al. Phytochemical analysis and biological activities of Cola nitida bark. Biochem Res Int 2015:1-12.

13. De Souza C, Ameganvi KK, Koumaglo K, Gbeassor M. Etude de l'activité antimicrobienne des extraits aqueux totaux de quelques plantes médicinales. Pharm Med Tra Afr 1995:103-12.

14. Donatus EO, Friday I. Phytochemical composition and biological activities of Uvaria chamae and Clerodendoron splendens. J Chemistry 2008;6:553-60.

15. Dougnon TV, Déguénon E, Fah L, et al. Traditional treatment of human and animal salmonelloses in Southern Benin: knowledge of farmers and traditherapists. Vet World 2017;10:580-92.

16. Etchiké AC, Ebanga Sassa A, Abba A, Nyonbourg E. Evaluation in vitro de l'activité antibactérienne de cinq plantes de la pharmacopée traditionnelle de l'Adamaoua (Cameroun). Cameroon J Exp Biol 2011;7:22-7.

17. Guede-Guina F, Vangah-Mandah M, Bonga GM, de Souza C. Activité antibactérienne d'un extrait végétale contre les germes opportunistes au cours du SIDA. Rev Med Tradition 1995;9:13-9.

18. Guessennd KN, Gbonon VC, Tiékoura KB, et al. Le GERBMR. Evolution de la résistance bactérienne à l'imipenème en Côte d'Ivoire de 2005 à 2009. Colloque scientifique de l'Institut Pasteur de Côte d'Ivoire: pathologies émergentes et biologie intégrative, 17 p. 2009.

19. Houngbeme AG, Gandonou C, Yehouenou B, et al. Phytochemical analysis, toxicity and antibacterial activity of Benin medicinal plants extracts used in the treatment of sexu- 
ally transmitted infections associated with HIV/aids. Int J Pharm Sci Res 2014;5:1739-45.

20. Iserin P. Larousse des plantes médicinales, identification, préparation, soins. Larousse. 2007;54:14-5.

21. Kanoun K, Abbouni B, Benine ML, et al. Étude de l'efficacité de l'extrait ethanolique d'écorces de Punica granatum linn sur deux souches phytopathogenes :ascocyhta rabiei (pass.) labr. et fusarium oxysporum f.sp.radicis-lycopersici. Eur Sci J $2014 ; 10$.

22. Kawsar SMA, Huq E, Nahar N. Cytotoxicity assessment of the aerial part of Macrotylomauniflorum Lim. Int J Pharm 2008;4:297-300.

23. Kim D, Chun O, Kim Y, et al. Quantification of phenolics and their antioxidant capacity in fresh plums. J Agric Food Chem 2003;51:6509-15.

24. Kooli I, Kadri Y, Abdallah HB, et al. Épidémiologie des bactéries multi-résistantes dans une unité néonatale tunisienne. J Pédiatrie Puériculture 2014;27:236-42.

25. Lagarto-Parra A, Yhebra RS, Sardinas IG, Buela LI. Comparative study of the assay of Artemia salina L. and the estimate of the medium lethal dose (LD50 value) in mice, to determine oral acute toxicity of plant extracts. Phytomedicine 2001;8:395-400.

26. McLauglin JL, Chang CJ, Smith DL. Simple bench-top bioassays (brine shrimp and potato discs) for the discovery of plant antitumour compounds. In: Human Medicinal Agents from Plants. Kinghorn AD, Balandrin MF. (Eds.) ACS Symposium 534, Washington DC.: American Chemical Society; 112-137. 1993.

27. Moshi MJ, Cosam JC, Mbwambo ZH, et al. Testing Beyond Ethnomedical Claims: brine shrimp lethality of some Tanzanian plants. Pharm Biol 2004;42:547-51.

28. Nsonde Ntandou GF, Banzouzi JT, Mbatchi B. Analgesic and anti-inflammatory effects of Cassia siamea Lam. stem bark extract. J Ethnopharmacol 2010;127:108-11.
29. Ogbulie JN, Ogueke CC, Nwanebu FC. Antibacterial properties of Uvaria chamae, Congronemalatifolium, Garcinia kola, Vemonia amygdalina and Aframomium melegueta. Afr J Biotechnol 2007;13:1549-53.

30. Oke MA, Bello AB, Odebisi MB, et al. Evaluation of antibacterial efficacy of some alcohol-based hand sanitizers sold in ilorin (north-central Nigeria). Ife J Sci 2013;15:111-7.

31. OMS. L'utilisation des antimicrobiens en dehors de la médecine humaine et les résistances qui en résultent chez 1'homme. OMS Aide-Mémoire N²68, Genève. 2002.

32. Rossolini GM, Mantengoli E. Antimicrobialresistance in Europeand itspotential impact on empiricaltherapy. Clin Microbiol Infect 2008;14:2-8.

33. Sanchez L de JT, do Nascimento Junior D, Diogo JM, et al. Botanical composition of the diet of oesophageally-fistulated bullocks on natural grassland in Vicosa. Rev Soc Bras Zootec 1993;22:839-51.

34. Saxena VK, Sharma RN. Antimicrobial activity of the essential oil of lantana camara. Filotherapia 1999;70:67-70.

35. Singleton VL, Orthofer R, Lamuela-Raventos RM. Analysis of total phenols and other oxidation substrates and antioxidants by means of Folin-Ciocalteu reagent. Methods Enzymol 1999;299;152-78.

36. Van Bambeke F, Spiniwine A, Verbist L, Tulkens PM. Les antibiotiques moins souvent et mieux: le rôle du pharmacien. Société scientifiques des pharmaciens francophones 2002:1-7.

37. World Health Organisation. A report of the consultation meeting on traditional and modern medicine: harmonizing two approaches, Beijing, China 2000: 22-26.

38. Zhishen J, Mengcheng T, Jianming W. The determination of flavonoid contents in mulberry and their scavenging effects on superoxide radicals. Food Chem 1999;64:555-9. 